\title{
Hybotinae (Diptera, Empidoidea, Hybotidae) from the Dominican Republic: new records and description of new species
}

\author{
Rosaly Ale-Rocha' \& José Albertino Rafael ${ }^{1,2}$
}

\begin{abstract}
${ }^{1}$ Coordenação de Pesquisas em Entomologia, Instituto Nacional de Pesquisas da Amazônia. Caixa Postal 478, 69011-970 Manaus-AM, Brazil E-mail: alerocha@inpa.gov.br; jarafael@inpa.gov.br ${ }^{2} \mathrm{CNPq}$ Fellowship.
\end{abstract}

\begin{abstract}
Resumo. Hybotinae (Diptera, Empidoidea, Hybotidae) da República Dominicana: novos registros e descrição de novas espécies. Hybotinae está sendo registrada pela primeira vez para a República Dominicana onde passa a ser representada pelos gêneros Euhybus Coquillett, 1895, Neohybos Ale-Rocha \& Carvalho, 2003 e Syneches Walker, 1852. Euhybus e Neohybos ocorrem exclusivamente nas Américas e Syneches é comopolita. Seis espécies novas são descritas e ilustradas: Euhybus martiniensis sp. nov., Neohybos cinereus sp. nov., N. longicornis sp. nov., $N$. pruinosus sp. nov., N. setosus sp. nov. e Syneches dominicanus sp. nov.. Chaves de identificação são fornecidas para as espécies desses três gêneros registradas nas Antilhas. As seguintes espécies são registradas pela primeira vez para a República Dominicana: Syneches inversus Curran, 1928, S. pallidus Wilder, 1974 e S. vineus Wilder, 1974. A fêmea de S. inversus é descrita pela primeira vez.

Palavras-Chave. Antilhas; Euhybus; Neohybos; Syneches; taxonomia.

ABstract. Hybotinae is being recorded for the first time to Dominican Republic where the subfamily becomes represented by the genera Euhybus Coquillett, 1895, Neohybos Ale-Rocha \& Carvalho, 2003 and Syneches Walker, 1852. Euhybus and Neohybos occur exclusively in the Americas, and Syneches is cosmopolitan. Six new species are described and illustrated: Euhybus martiniensis sp. nov., Neohybos cinereus sp. nov., N. longicornis sp. nov., N. pruinosus sp. nov., $N$. setosus sp. nov. and Syneches dominicanus sp. nov.. Identification keys are provided for the species of the three hybotine genera registered in West Indies. The following species are recorded for the first time from the Dominican Republic: Syneches inversus Curran, 1928, S. pallidus Wilder, 1974 and S. vineus Wilder, 1974. The previously unknown female of S. inversus is described.
\end{abstract}

KEYwords. Euhybus; Neohybos; Syneches; taxonomy; West Indies.

Up to now no records of Hybotinae (Empidoidea, Hybotidae) had been made to the Dominican Republic, although several species of this subfamily have been recorded from other parts of the West Indies (Melander 1965; SMith 1967; Wilder 1974; Rogers 1983; Dalmau \& Ávila 1983). The opportunity to study the material from the Carnegie Museum of Natural History (CMNH), Pittsburgh, USA, American Museum of Natural History (AMNH), New York, USA, The Natural History Museum (BMNH), London, England and Canadian National Collection (CNC), Ottawa, Canada, revealed six new species and three new geographical records of Hybotinae. The subfamily is represented in the Dominican Republic by the genera Euhybus Coquillett, 1895, Neohybos Ale-Rocha \& Carvalho, 2003 and Syneches Walker, 1852.

Euhybus and Neohybos occur exclusively in the Americas. These genera plus Cerathybos Bezzi, 1909 form the Neotropical group of hybotines with short membranous proboscis bearing pseudotracheae; eyes holoptic or narrowly dichoptic on face; palpus slender and as long as proboscis, with preapical seta; one pair of ocellar setae; posterior setae of scutum proclinate; Rs vein short; male terminalia asymmetrical. Euhybus and Neohybos differ from Cerathybos by the ovate flagellum and outstanding setae on the fore and mid tarsomeres; Neohybos distinguishes from Euhybus and Cerathybos by the hypandrial arms narrowed forming a sclerotized ring around the phallus and the medium portion of the hypandrium wider than the base. In Euhybus and Cerathybos the hypandrial arms are prolonged distally forming a dorsolateral chamber and the hypandrium is narrowed medially.

Syneches is cosmopolitan and characterized by a flattened frons; eyes broadly dichoptic on face; proboscis long and slender; labellum sclerotized, without pseudotracheae; palpus long bristled, about half as long as proboscis; antennae placed below the middle of the head; flagellum with dorsal seta and dorsoapical arista; two ocellar pairs of setae; $1 \mathrm{dc}$ posterior long and strong; Rs long, arising before middle of basal cells; male terminalia symmetrical with one pair of long postgonites.

\section{MATERIAL AND METHODS}

The terminalia were removed from the abdomen, treated with hot $85 \%$ lactic acid according to CUMMING (1992), and kept in a microvial with glycerin. The wing was illustrated after being removed from the body and mounted between coverslips. The microvials and the microslides were pinned together with the specimen. Primary types are deposited at $\mathrm{CMNH}$, and representative paratypes at the Instituto Nacional de Pesquisas da Amazônia (INPA), Manaus, Brazil.

The terminology follows MCAlpine (1981), except for male terminalia which follows Cumming et al.(1995). Abbreviations: $\mathrm{A}$, anterior; acr, acrostichal setulae; $\mathrm{AV}$, anteroventral; $\mathrm{AD}$, anterodorsal; D, dorsal; dc, dorsocentral bristles; npl, 
notopleural bristles; P, posterior; pal, postalar bristle; PD, posterodorsal; presut spal, presutural supra-alar bristles; psut spal, postsutural supra-alar bristles; PV, posteroventral; sctl, scutellar bristles; St, sternite; Tg, tergite; V, ventral.

\section{Euhybus Coquillett, 1895}

Euhybus Coquillett, 1895:437 (genus description); 1903:250 (type species designation); Melander, 1928:24 (key); 1965:448 (catalog); Smith, 1967:11 (catalog).

Type species: Hybos purpureus Walker, 1849, by subsequent designation.

Includes 50 species (Melander 1965; SMith 1967; Rafael \& Ale-Rocha 1995; Ale-Rocha 2002). Four species have been reported in the West Indies (Cuba, Puerto Rico and Jamaica) (Sмiтн 1967): E. electus (Melander, 1902), E. spinosus (Curran, 1928), E. spiniger Melander, 1927 and E. subjectus (Walker, $1849)$. The types of E. subjectus and E. spiniger were examined. The type of E. electus was not examined but it can be distinguished from others known species of Euhybus occurring in West Indies by the original description and the key provided by MeLANDER (1928). E. spinosus was included in couplet 3 of the key below with $E$. spiniger because the type species of the former was not examined and its original description (CURRAN 1928) did not allow to differentiate it from E. spiniger. The first author is carrying out the revision of the Neotropical species of Euhybus.

Key to species of Euhybus recorded to West Indies

1. Wing base darker than apex ............................................... 2 Wing hyaline to slightly brown tinged (Figs. 48-52) ....... 3

2(1). Costal cell slightly wide; pterostigma clear, almost hyaline E. subjectus (Walker)

Costal cell narrow; pterostigma brown tinged, conspicuous ................................... E. electus (Melander)

3 (1).Pterostigma hyaline; left epandrial lamella with 2 robust, spine-like straight projections at distal margin, almost as long as epandrium ........... E. spiniger Melander and E. spinosus (Curran)
Wing brown colored, pterostigma tinged (Fig. 48); distal margin of the epandrial lamellae with long slender curved process (Figs. 2-5) E. martiniensis sp. nov.

\section{Euhybus martiniensis sp. nov.}

(Figs.1-6, 48)

Diagnosis: thorax black, brown pruinose except for scutum and pronotum shiny dorsally, pleura with shiny spot on anepisternum and katepisternum; abdomen shiny brown except Tg1 and distal margin of Tg8 gray pruinose; body setae pale-brown; legs pale-brown except mid tibia and all tarsomeres 1-2 yellow, coxa, femur and tibia of hind leg and remaining tarsomeres brown; wing narrow, pale-brown, with darker stigma and reduced anal lobe.
Holotype male. Body length $3.4 \mathrm{~mm}$; wing length $3.2 \mathrm{~mm}$. Head. Antenna placed slightly below middle of head; first flagellomere elongate oval, twice as long as wide and as long as scape and pedicel together. Eyes holoptic on face. Face about $3 / 4$ of frons length. Palpus preapical seta long and upcurved. Ocellar pair convergent, proclinated at $45^{\circ}$. Upper postocular setae bent at basal third. Postcranium brownishgray pruinose; row of occipital setae short, starting opposite postocular row, uniserial but disordered above, multiserial and abundant below.

Thorax black, brown pruinose except scutum and pronotum shiny dorsally and pleura with shiny spot on anepisternum and katepisternum; pronotum with marginal dark uniserial setae. Scutum rounded dorsally with thin yellow short setae; acr biserial anteriorly and numerous on prescutellar disc; $\mathrm{dc}$ uniserial on the middle of scutum, more numerous on presutural region and prescutellar disc; ial and spal setae numerous. Laterotergite with conspicuous whitish setulae. Outstanding setae: $2 \mathrm{ntpl}$; 1 pal; sctl with 1 pair of straight, spine-like, rather short setae and 4 thin lateral setae about $1 / 4$ as long as the larger pair (Fig. 1). Propleural seta very short and weak.

Legs clothed with thin yellow setae. Fore and mid coxae and femora, and fore tibia pale-brown; mid tibia and all tarsomeres 1-2 yellow; coxa, femur and tibia of hindleg and remaining tarsomeres brown. Outstanding setae: mid tibia with several AD short setae and $1 \mathrm{~V}$ black preapical seta as long as tarsomere 1; fore tarsomere 1 with 1D seta near middle and 1D preapical seta; mid tarsomere 1 as fore tarsi except for $2 \mathrm{PV}$ long and robust setae near base; hind trochanter with $1 \mathrm{~V}$ spine; hind femur strongly thickened, 4 times as long as wide, with $1 \mathrm{AD}$ seta near apex and $1 \mathrm{~A}$ at distal quarter, $8 \mathrm{AV}$ spines rather long, $6 \mathrm{~V}$ spines decreasing in length apically, spines of distal half with more protuberant bases, 5PV rather long spines on distal half and one near base. Hind tibia slightly flattened. Hind tarsi without spines.

Wing (Fig. 48): long, narrow; pale-brown, almost hyaline; anal lobe poorly developed; costal cell narrow; pterostigma lightly brownish, darker than wing, filling out end of cell $r_{1}$.

Abdomen shining brown with yellow thin dense setae. $\operatorname{Tg} 1$ and distal margin of $\operatorname{Tg} 8$ sparsely gray pruinose. $\operatorname{Tg} 1$, lateral of $\operatorname{Tg} 2$ and $\operatorname{Tg} 3$ with long setae, remaining setae short. Sternites long haired. Segment 8 rotated $90^{\circ}$ to right. Abdomen strongly narrowed medially, between $\mathrm{Tg} 2$ and $\mathrm{Tg} 3$; base of $\mathrm{Tg} 2$ more than 1.5 times as wide as apex; $\mathrm{Tg} 3$ to $\mathrm{Tg} 5$ progressively shorter and wider toward apex; $\operatorname{Tg} 6$ and $\operatorname{Tg} 7$ subequal in size; $\operatorname{Tg} 8$ as wide as $\mathrm{Tg} 7$. Terminalia (Figs. 2-6): hypandrial base widened, deeply bilobed apically, with few thin preapical setae; right bacilliform sclerite with simple long and slender process distally.

Female: unknown.

Holotype male. DOMINICAN REPUBLIC. Azua: East side of crest, Sierra Martin Garcia, $7 \mathrm{Km}$ WNW Barrero, 18-21N, 70-58W, 860m, 25-26.VII.1992, C. Young, R. Davidson, S. Thompson, J. Rawlins, cloud forest adjacent to disturbed forest (right antenna lost, right wing 


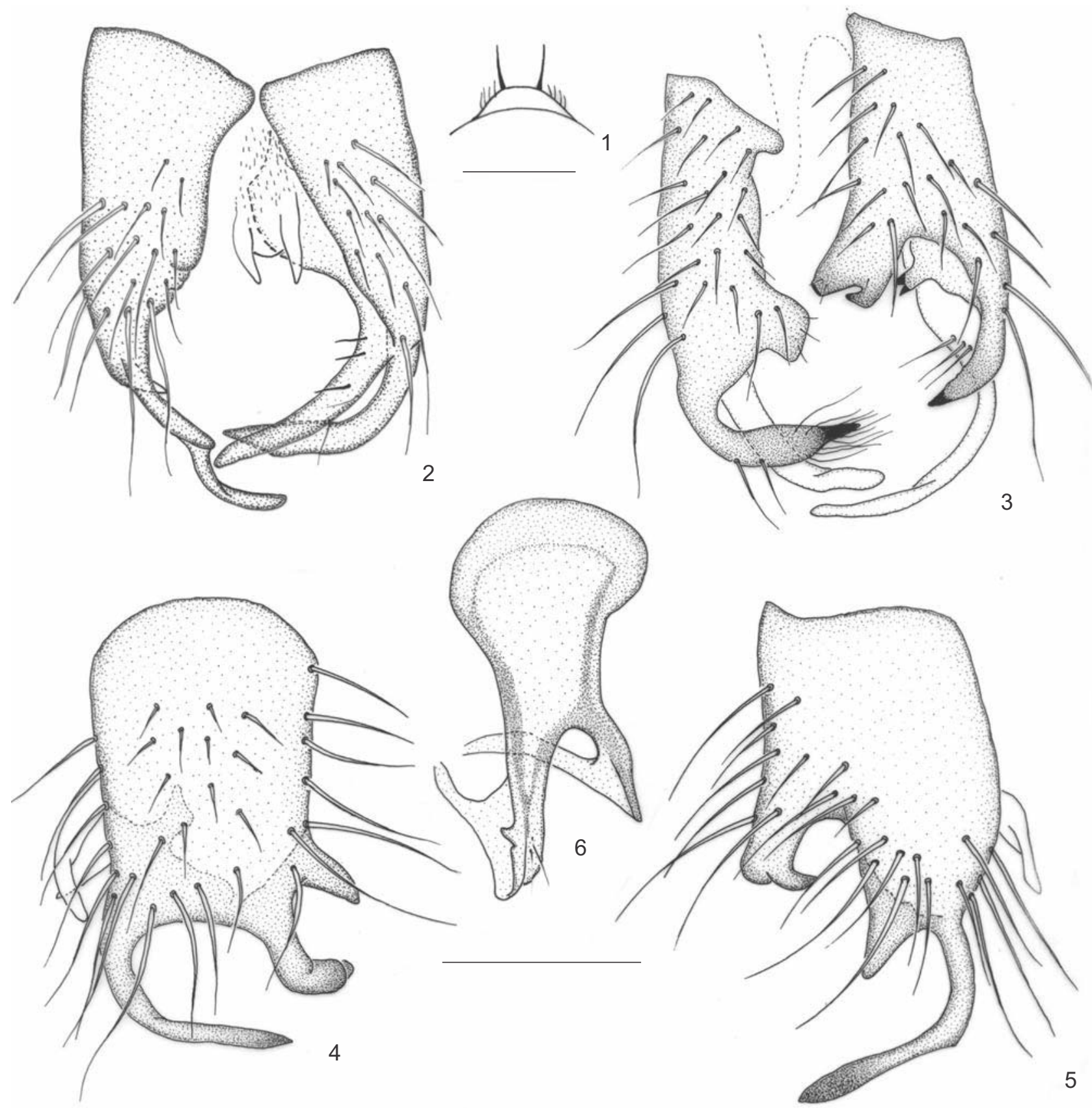

Figs. 1-6. Euhybus martiniensis sp. nov. Holotype male: 1, scutellum; 2-3, epandrium, dorsal and ventral view; 4, right epandrial lamella; 5, left epandrial lamella; 6, hypandrium, ventral view. Scale bars: fig. $1=0.5 \mathrm{~mm} ; 2-5=0.3 \mathrm{~mm}$.

mounted in microslides, abdomen in tube with glycerin, $\mathrm{CMNH}$ ).

Remarks. Euhybos martiniensis sp. nov. belongs to the $E$. neotropicus species-group by the narrow costal cell, faintly developed anal lobe and scutum with scattered bristles. It differs of all the other species of Euhybus recorded for West Indies by the pale-brown wing and pterostigma tinged. It is very close to E. spiniform and E. spinosus differing by the long slender curved process on distal margin of the epandrial lamellae.
The specific name refers to the type locality, Sierra Martin Garcia.

Neohybos Ale-Rocha \& Carvalho, 2003

Neohybos Ale-Rocha \& Carvalho, 2003:1 (genus description).

Type species: Hybos luridus Bezzi, 1909, by original designation.

Occurs exclusively in the Neotropical Region with records on Central America and northern of South America and includes 
five species (Ale-Rocha \& CARvalho 2003). In this work we are increasing more four species from West Indies.

Key to species of Neohybos recorded to West Indies

1. Anterior portion of the scutum pruinose; scutellum with several pairs of developed setae (Figs. 22, 31) .......... 2

Anterior portion of the scutum shiny; scutellum with one pair of developed setae (Figs. 7,13) 3

2(1). Male hind tibia falciform; hind femur with ventral preapical semicircle of 6 spines mounted on tubercles; male scutellum with 3 pairs of stout setae (Fig. 22), tarsomeres 1-2 yellow ................... . pruinosus sp. nov.

Male hind tibia straight; hind femur with ventral spines arranged in straight line with bases slightly protuberant; male scutellum with 4 pairs of stout setae (Fig. 31); all tarsomeres dark brown to black

N. setosus sp. nov.

3 (1). Distal margin of the epandrial lamellae truncated (Figs. $10,11)$; right bacilliform sclerite with a hook-like process curved towards ventral surface (Figs. 8, 11); right epandrial lamella simple (Fig. 11)

N. cinereus sp. nov.

Distal margin of the epandrial lamellae not truncated (Figs. $16,17)$; right bacilliform sclerite with a long sinuous process bearing an acute projection near base (Fig. 14); right epandrial lamella with an elongated process (Fig.16) N. longicornis sp. nov.

\section{Neohybos cinereus sp. nov.}

(Figs. 7-12, 49)

Diagnosis: black with yellow setae; thorax pruinose except shiny T-shaped area without pruinescence on anterior third of scutum; acr uniserial; coxae, trochanters and femora black, apex of femora yellow; fore tibia mainly pale brown with dorsal surface, apex and base yellow; mid tibia yellow; fore and mid tarsomeres 1-2 yellow, except for apex of tarsomere 2 brown, tarsomeres 3-5 brown; hind tibia brown, with yellowish base and pale brown dorsal surface; hind tarsomere 1 yellow with brown apex, tarsomeres 2-5 brown; wing narrow, pale brown, with dark pterostigma.

Holotype male. Body length $3.4 \mathrm{~mm}$; wing $3.2 \mathrm{~mm}$. Head: antenna placed at middle of head; first flagellomere elongate oval, twice more long than wide, as long as scape and pedicel together. Postcranium gray pruinose. Face linear, as long as frons. One pair of parallel ocellar setae. Upper postocular setae long and proclinate; occipital setae arranged in 2 rows behind postocular row, outward row beginning behind vertical seta of upper postocular row, inner row beginning behind ocellar setae level.
Thorax black, scutum brown pruinose except shiny Tshaped area on anterior third; dorsum of scutellum without pruinescence; pleurae weakly gray pruinose. Pronotum long with marginal setae. Scutum rounded dorsally, not greatly convex, with yellow sparse slender setae; setae of prescutellar disc short; acr and de uniserial; spal presut setae numerous. Outstanding setae: 2 long ntpl; 1 pal; 1 pair of apical sctl spinelike setae and 4 weak lateral setae about 1/4 length of apical pair (Fig. 7).

Legs clothed in slender yellow setae, longer on coxae and femora. Coxae, trochanters and femora black, apex of femora yellow; fore tibia mainly pale brown, with dorsal surface, apex and base, yellow; mid tibia yellow; fore and mid tarsomeres 1 and 2 yellow, with apex of tarsomere 2 brownish, tarsomeres 3 5 brown; hind tibia brown, with yellow base and dorsal surface pale brown; hind tarsomere 1 yellow with brown apex, tarsomeres 2-5 brown. Outstanding setae: fore tibia with $1 \mathrm{AV}$, 1PV near apex; fore tarsomere 1 with 1A long and 1D short at basal half, 1D short near apex; mid tibia with $1 \mathrm{~V}$ apical as long as tarsomere 1; mid tarsomere 1 as the fore ones, except for the 2PV setae near basal half, the apical about twice the length of basal one; hind trochanter with 1V spine; hind femur thickened, 4.5 times more long than wide, with $1 \mathrm{~A}$ seta at apical quarter, 2AD near apex, row of 9AV long spines, row of 9V shorter tuberculated spines on distal half and 1 spine near base, PV row with 4 spines on apical third and 1 spine near base. Hind tibia simple. Hind tarsi without spines. All pulvilli of same length.

Wing (Fig. 49): long; pale-yellow, almost hyaline; pterostigma brown; costal cell narrow; anal lobe reduced; $\mathrm{R}_{4+5}$ and $\mathrm{M}_{1}$ parallel-sided.

Abdomen black, shiny, narrowed medially, widened towards tip in dorsal view, with setae yellow and slender. TG1 and T8 sparsely brown pruinose. T2-T4 over 1.5 times more long than wide, remaining tergites shorter and wider. $\mathrm{T} 8$ visible only on right side. Tergites short setose except TG1, lateral margins of T 2 and T3 with long setae. St 8 distal margin densely setose; segment 8 not rotated. Terminalia (Figs. 8-12): hypandrium with numerous long preapical bristles, deeply bilobed apically, right apical lobe about twice the length of left one; distal margin of the epandrial lamellae truncate; right bacilliform sclerite with hook-like process curved towards ventral surface.

Female: unknown.

Holotype male. DOMINICAN REPUBLIC. Independencia: Sierra de Neiba just south of crest, $5 \mathrm{Km}$ NNW Angel Feliz, 1780m, 18-41N, 71-47W, 13-15.X.1991, J. Rawlings, R. Davidson, C. Young, S. Thompson, cloud forest (right wing mounted in microslides; terminalia in microvial with glycerin; right flagellum and arista lost, $\mathrm{CMNH}$ )

Remarks. Neohybos cinereus sp. nov. is very close to $N$. longicornis sp. nov. differing by the truncated distal margin of the epandrial lamellae and right bacilliform sclerite with a hooklike process curved towards ventral surface.

The specific name refers to the color of the pruinosity of 

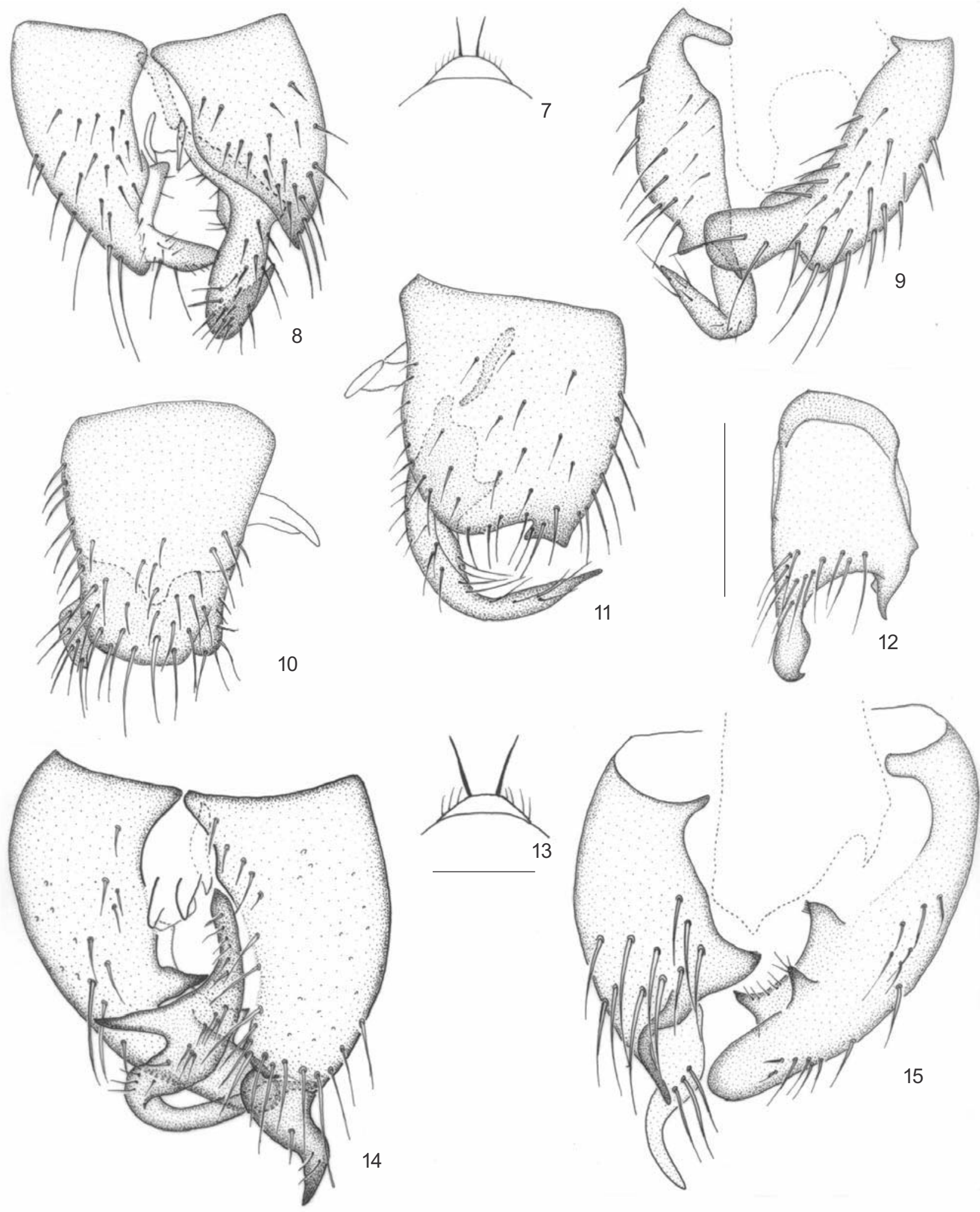

Figs. 7-15. Neohybos cinereus sp. nov. Holotype male: 7, scutellum; 8-9, epandrium, dorsal and ventral view; 10, left epandrial lamella; 11, right epandrial lamella; 12, hypandrium, ventral view. $N$. longicornis sp. nov. Paratype male: 13, scutellum; 14-15, epandrium, dorsal and ventral view. Scale bars: figs. $7,13=0.5 \mathrm{~mm} ; 8-12,14,15=0.3 \mathrm{~mm}$. 
pleurae.

\section{Neohybos longicornis sp. nov.}

(Figs. 13-21, 50)

Diagnosis: thorax black, gray pruinose except pronotum, scutum, postpronotal lobe and scutellum shiny dorsally, acr uniserial; abdomen shinning brown; body covered with yellow setae; legs brown except fore and mid tibiae yellow; fore and hind tarsomeres 1-2 yellow with brown tips; posterior surface of fore tibia with long setae near apex; wing narrow, paleyellow, with brown pterostigma and reduced anal lobe.

Holotype male. Body length $4.9 \mathrm{~mm}$; wing length $4.1 \mathrm{~mm}$. Head. Antenna placed at middle of head; first flagellomere elongate oval, twice as long as wide and as long as scape and pedicel together. Face linear, as long as frons. Palpus with short and almost straight preapical seta. Postcranium gray pruinose; upper postocular setae bent in middle at almost ninety degrees; occipital setae straight, beginning just above middle of postcranium, uniserial in the upper half of postcranium, multiserial below.

Thorax black, gray pruinose except dorsum of pronotum, scutum, postpronotal lobe and scutellum shiny. Scutum rounded dorsally, not greatly convex with sparse setae longer laterally; acr and dc uniserial; spal numerous mainly on presutural region. Pronotum elongated. Outstanding setae: 2 long ntpl; 1 pal; 1 apical pair of straight and divergent sctl and 3 outer lateral slender setae about $1 / 4$ as long as apical pair (Fig. 13).

Legs brown except fore and mid tibiae yellow; fore and mid tarsomeres 1-2 and hind tarsomere 1, yellow with brown tips; legs covered with short, slender, yellow setae; posterior surface of fore tibia with long setae near apex. Outstanding setae: fore tibia with $1 \mathrm{AV}$ and $1 \mathrm{PV}$ near apex, the PV reaching middle of tarsomere 1; mid tibia with 4-5AD short, 1PV preapical almost as long as tarsomere 1; fore tarsomere 1 with $1 \mathrm{~A}$ long setae near middle; mid tarsomere 1 with $1 \mathrm{D}$ in middle, 1D preapical long and 2PV near base, most distal seta as long as tarsomere 1, 1PV preapical short; hind trochanter with $1 \mathrm{~V}$ spine; hind femur thickened, 4.4 times as long as wide; with $1 \mathrm{~A}$ and $1 \mathrm{AD}$ at distal quarter, $1 \mathrm{AD}$ preapical, row of $7 \mathrm{AV}$ spinelike setae with 3 on basal third and 4 on distal third, ventral row with 8 spines on basal 2/3 and 5-6 very short spines near apex, row of 7PV setae on distal half and 1 near base. Hind tibia almost straight with ventral surface sharpened at basal $2 / 3$ and rounded at remaining. Hind tarsomere 1 with $1 \mathrm{~A}$ short preapical seta.

Wing (Fig. 50): long, pale-yellow, almost hyaline; pterostigma brown filling cell $r_{1}$ apex; costal cell narrow; $R_{1}$ very long; anal lobe reduced.

Abdomen shining brown except T1 sparsely gray pruinose; cylindrical; with yellow slender setae. Tergites short setose dorsally; dorsolateral margin of T1-T3 with setae longer than the others. Sternites long setose. Proportions of T2 to T4 as in N. cinereus sp. nov. T8 visible only in lateral view; segment 8 not rotated. Terminalia (Figs. 14-18): hypandrium with numerous long preapical setae, right apical lobe widened, left apical lobe reduced; right bacilliform sclerite with a long sinuous process bearing an acute projection near base.

Female. Similar to male except as follows: hind femur slender basally and thickened towards tip, AD preapical setae absent, AV row with 5-6 setae on distal 2/3 and 1 subbasal seta, V row with few short spines on distal third, PV row with 3 setae near apex and long and slender setae complete the row to the base; hind trochanter without ventral spine. Wing hyaline with palebrown pterostigma. Terminalia (Figs.19-21): dorsoapical margin of T7 deeply marginate; T7 and S7 partially fused at lateral margin; T8 and S8 short, S8 about half of the length of T8 with long and conspicuous slender setae; cercus short.

Holotype male. DOMINICAN REPUBLIC. Pedernales: Upper Las Abejas, 38 Km NNW Cabo Rojo, 18-09N, 71-38W, 1350m, 22.VII.1990 L. Masner, Mesic deciduous forest, sweeping (some thoracic setae lost). Paratypes: same data of holotype, 4 males, 4 females (CMNH), 2 males, 2 females (INPA); 1250m, 15.VII.1987, J. E. Rawlins, R. L. Davidson, 6 males, 2 females (CMNH), 2 males (INPA).

Remarks. Neohybos longicornis sp. nov. is very close to $N$. cinereus sp. nov. differing by the elongated distal margin of the epandrial lamellae, right bacilliform sclerite with a long sinuous process bearing an acute projection near base and right epandrial lamella with an elongated process.

The specific name refers to the long and curved spine-like process of the right bacilliform sclerite.

\section{Neohybos pruinosus sp. nov.} (Figs. 22-30, 51)

Diagnosis: body brown to black; thorax densely pruinose with black setae; abdomen shiny except T1 and T8 pruinose; S8 with fringe of setae on distal margin; legs brown to black except apex of femora, base of tibiae and dorsal surface of the mid tibia pale-brown to yellow, tarsomeres 1-2 yellow with dark brown tips; hind tibia falciform, anterior surface convex at basal half for fitting the preapical spines arranged in semicircle on ventral surface of hind femur; scutellum with 3 pairs of spine-like setae.

Holotype male. Body length $4.5 \mathrm{~mm}$; wing length $3.9 \mathrm{~mm}$. Head. Antenna placed slightly below the middle of head; first flagellomere 3 times as long as wide, as long as scape and pedicel combined. Face brown pruinose, narrow, and about half as long as frons. Palpus with preapical upcurved long seta. Ocellar pair slightly proclinate. Postcranium brown pruinose; upper postocular setae bent almost $90^{\circ}$; inferior postocular setae short, almost straight at postcranium margin; occipitals short, multiserial and abundant.

Thorax dark brown, densely pruinose, no shiny areas; scutum with dense gray to brown pruinescence; scutellum and pleura gray pruinose. Pronotum short, with uniserial short spine-like marginal setae. Scutum slightly convex, almost 

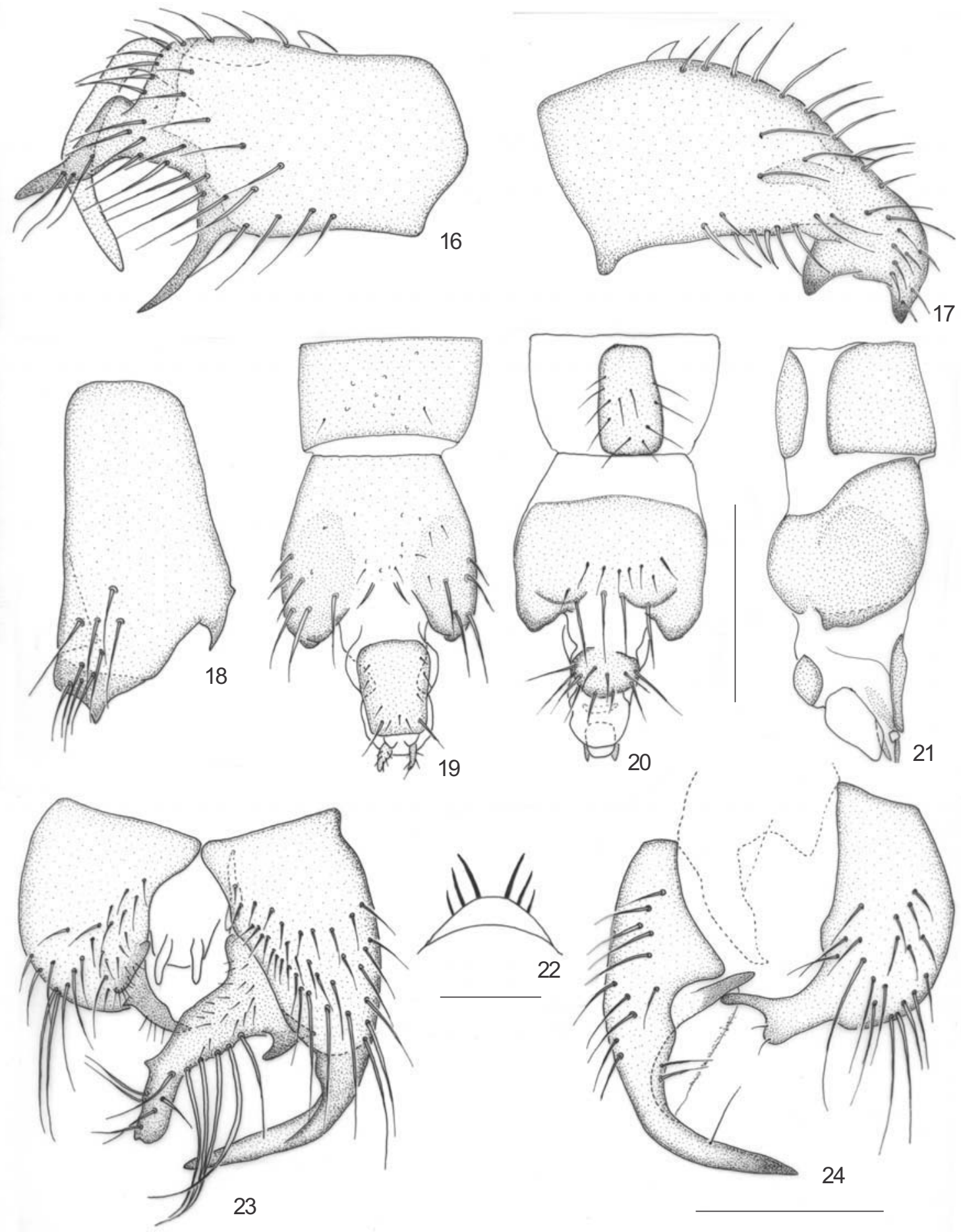

Figs. 16-24. Neohybos longicornis sp. nov. Paratype male: 16, right epandrial lamella; 17, left epandrial lamella; 18, hypandrium, ventral view. Paratype female: 19-21, terminalia, dorsal, ventral and lateral view. N. pruinosus sp. nov. Paratype male: 22, scutellum; 23-24, epandrium, dorsal and ventral view. Scale bars: figs. $16-18,23,24=0.3 \mathrm{~mm} ; 19-22=0.5 \mathrm{~mm}$.

flattened dorsally, with short, slender, sparse black setae; acr and dc uniserial; ial and spal numerous. Outstanding setae: 2 ntpl; 2 dc posterior; 1 pal; 3 pair of sctl spine-like setae (Fig. 22).

Legs brown to black except apex of femora, base of tibiae and dorsal surface of mid tibia pale-brown to yellow, tarsomeres 1-2 yellow with dark brown tips with thin coating, yellow and short setae. Outstanding setae: fore tibia with $1 \mathrm{~A}$ and $1 \mathrm{P}$ preapical setae; mid tibia with some $\mathrm{AD}, 1 \mathrm{~A}$ and $1 \mathrm{P}$ short preapical, $1 \mathrm{~V}$ preapical longer than tarsomere 1 ; fore tarsomere 
1 with $1 \mathrm{~A}$ at basal third, $1 \mathrm{D}$ at middle, $1 \mathrm{~A}, 1 \mathrm{D}$ and $1 \mathrm{P}$ preapical setae; mid tarsomere 1 as in foreleg except 1PV very long seta near base; hind femur thickened, 4.4 times as long as wide, with $1 \mathrm{AD}$ at distal quarter and $1 \mathrm{~A}$ near apex, $5 \mathrm{AV}$ spine-like setae, $3 \mathrm{~V}$ spines on basal half and short spines with protuberant bases arranged in semicircle on ventral surface on distal half, 1PV subbasal spine and 3 spine-like setae with protuberant bases at distal half; hind tibia with 1A apical seta; hind tarsomere 1 with $1 \mathrm{~A}$ apical spine and some slender ventral spines. Hind trochanter without spines. Hind tibia falciform, anterior surface convex at basal half for fitting preapical spines on ventral surface of hind femur. Fore and mid pulvilli slightly longer than hind ones.

Wing (Fig. 51): narrow, elongate; pale-brown with brown pterostigma filling distal third of cell $r_{1}$; costal cell narrow; anal lobe developed; anal angle $90^{\circ}$.

Abdomen shining brown except T1 and T8 sparsely gray pruinose. Setae yellow and slender. T1 and dorsolateral margin of T2 and T3 with long setae, remaining setae of tergites short. Sternites long haired. Abdomen cylindrical with rather parallel sides; T2-T6 subequal in length, decreasing slightly in length distally. Segment 8 not rotated. T8 visible on left side only. S8 long with fringe of long setae on distal margin. Terminalia (Figs. 23-27): right bacilliform sclerite with a long oblique process, narrowed distally, with long bristles on posterior margin; hypandrium with three short slender bristles, right apical lobe elongate and conspicuously convex apically.

Female. Similar to male except as follows: abdomen black; hind femur slender, AV row absent, V row with 4 spine-like setae at basal half and 5 very close setae arranged in oblique line on distal quarter, PV surface with 5 spine-like setae on distal quarter; hind tibia simple; mid and hind pulvilli elongate. Terminalia (Figs. 28-30): T7 elongate and narrowed medially; T8 wide on basal half; S7 protuberant and strongly sclerotized distally. Cercus slender.

Holotype male, DOMINICAN REPUBLIC. Independencia: Sierra de Neiba near crest, 5.5 Km NNW Angel Feliz 18-41N, 71-47W, 1750m, 21-22.VII.1992, J. Rawlins, S. Thompson, C. Young, R. Davidson, dense cloud forest (not dissected, $\mathrm{CMNH}$ ). Paratypes: same data of the holotype, 1 male (INPA); $32 \mathrm{Km}$ La Descubierta, Sierra de Neiba, 1,85m, 1-5.XII.1991, L. Masner, S. Peck, montane forest, malaise trap, 1 female $(\mathrm{CMNH})$.

Remarks. Neohybos pruinosus sp. nov. is very close to $N$. setosus sp. nov. differing by the male with a falciform hind tibia, hind femur with ventral preapical semicircle of 6 spines mounted on tubercles, male scutellum with 3 pairs of stout setae and tarsomeres 1-2 yellow.

The specific name refers to the dense body pruinescence.

\section{Neohybos setosus sp. nov.}

(Figs. 31-39, 52)

Diagnosis: body black; thorax densely pruinose with black setae; scutellum with 4 pairs of thick spines; legs mainly black with tips of femora, bases of tibiae and bases of tarsomeres 1 pale-brown; legs covered with slender yellow setae; posterior surface of fore and mid tibiae with fringe of long setae; wing pale-brown with brownish pterostigma; abdomen shiny except T1 and T8 pruinose; T1 to T4 with long lateral setae; S8 with fringe of setae on distal margin.

Holotype male. Body length $5.4 \mathrm{~mm}$; wing length $4.8 \mathrm{~mm}$. Head slightly more wide than high. Antenna placed slightly below middle of head, brown pruinose; first flagellomere elongate, oval, 2.5 times as long as wide, slightly longer than scape and pedicel combined. Face narrow, about half as long as frons, brown, pruinose. Palpus with preapical dorsal long upcurved hook-like seta. Ocellar pair slightly proclinate. Postcranium long haired, gray pruinose; upper postoculars bent on distal third, absent below; occipital setae straight, numerous, disordered, shorter than postoculars, completely filling height of postcranium.

Thorax black except for postalar callus with yellow spot. Pronotum short, brown pruinose, with numerous marginal spine-like setae. Scutum brown pruinose anteriorly, gray pruinose on prescutellar disc and scutellum; pleura gray pruinose. Scutum slightly flattened dorsally; with short and sparse setae dorsally, rather long laterally; acr with 2-3 rows on anterior third and uniserial on remaining portion of scutum; dc uniserial; ial and spal numerous and disordered on notopleural level, arranged in row above postalar callus; prpl short. Outstanding setae: 2 ntpl; 1 pal; 4 sctl pairs of thick spines (Fig. 31).

Legs mostly black with tips of femora, bases of tibiae and basal portion of tarsomeres 1 pale-brown; clothed densely with yellow setae. Fore and mid tibiae with fringe of long thin setae on posterior surface; fore and mid tarsi with long thin black setae on dorsal surface and yellow pilosity ventrally. Outstanding setae: fore tarsomere 1 with $2 \mathrm{AV}$ elongate subbasal setae, $1 \mathrm{~A}$ weak, $1 \mathrm{AD}$ and $1 \mathrm{P}$ preapical setae; mid tibia with $1 \mathrm{~V}$ preapical long black seta, some AD thickened and other preapical short setae; mid tarsomere 1 as in foreleg except 1A subbasal, 1D near middle and 1PV subbasal setae longer than those on fore tarsomere; hind trochanter with $1 \mathrm{~V}$ spine; hind femur very thick, 4 times as long as wide, with 1D and $1 \mathrm{~A}$ setae at distal quarter, $10 \mathrm{AV}$ short spine-like setae, $5 \mathrm{~V}$ spine-like setae on basal half and 10 short spines with protuberant bases on distal half, 3PV spine-like setae on basal third and slender setae on distal third; hind tibia with 1A apical seta; hind tarsomeres 1-2 with 1A apical short spine; hind tibia flattened anteriorly, rounded dorsally, with ridge ventrally.

Wing (Fig. 52): pale-brown, pterostigma brown filling apex of cell $\mathrm{r}_{1}$; costal cell narrow; anal angle acute; anal lobe developed.

Abdomen slightly narrowed medially, with yellow thin setae. Tergites shining black except $\mathrm{T} 1$ and $\mathrm{T} 8$ with gray pruinescence; sternites brown. Setae short except on dorsolateral margin of T1 - T4 and sternites with long setae. T7 partially covered by T6. T7 and T8 subequal in length, about half as long as T6. T8 visible on left side only. Segment 


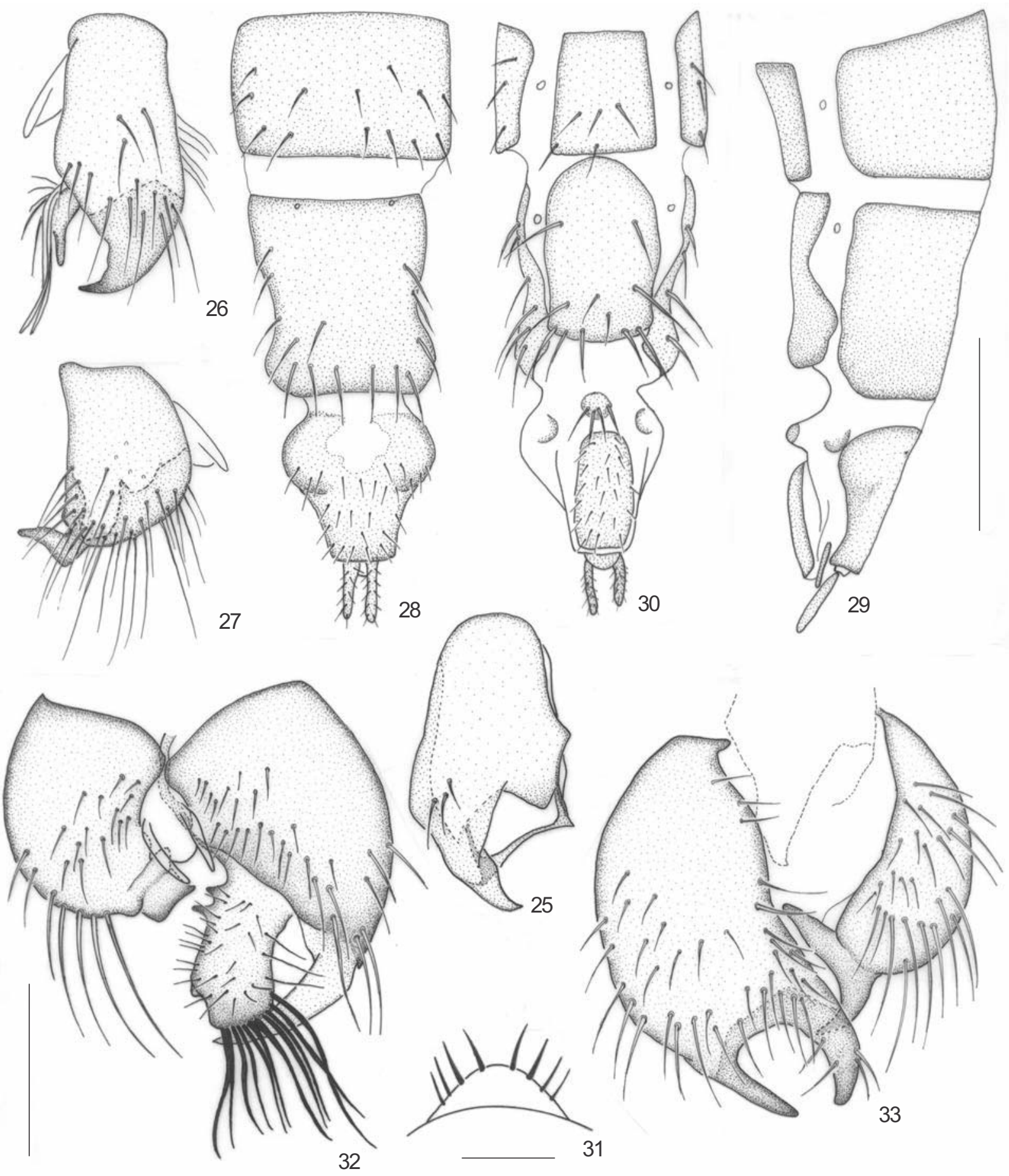

Figs. 25-33. Neohybos pruinosus sp. nov. Paratype male: 25, hypandrium, ventral view; 26, right epandrial lamella; 27, left epandrial lamella. Paratype female: 28-30, terminalia, dorsal, lateral and ventral view. N. setosus sp. nov. Holotype male: 31, scutellum; 32-33, epandrium, dorsal and ventral view. Scale bars: figs. $25-27,32,33=0.3 \mathrm{~mm} ; 28-31=0.5 \mathrm{~mm}$.

8 not rotated to right. Basal sternites longer and narrower than apical ones; S8 with fringe of setae on distal margin; S2 longer than T2. T2-T6 decreasing slightly in length distally. Terminalia (Figs. 32-36): right bacilliform sclerite with large vertical process, with truncate apex bearing numerous long black robust bristles; hypandrium with numerous long bristles, right apical lobe triangular, left apical lobe inconspicuous.

Female. Similar to male except as follows: slender marginal and sparse setae of pronotum; fore and mid tibiae and tarsi without fringe of long setae; hind trochanter without spine; hind femur more slender than male femur, AV row with 7 setae, 

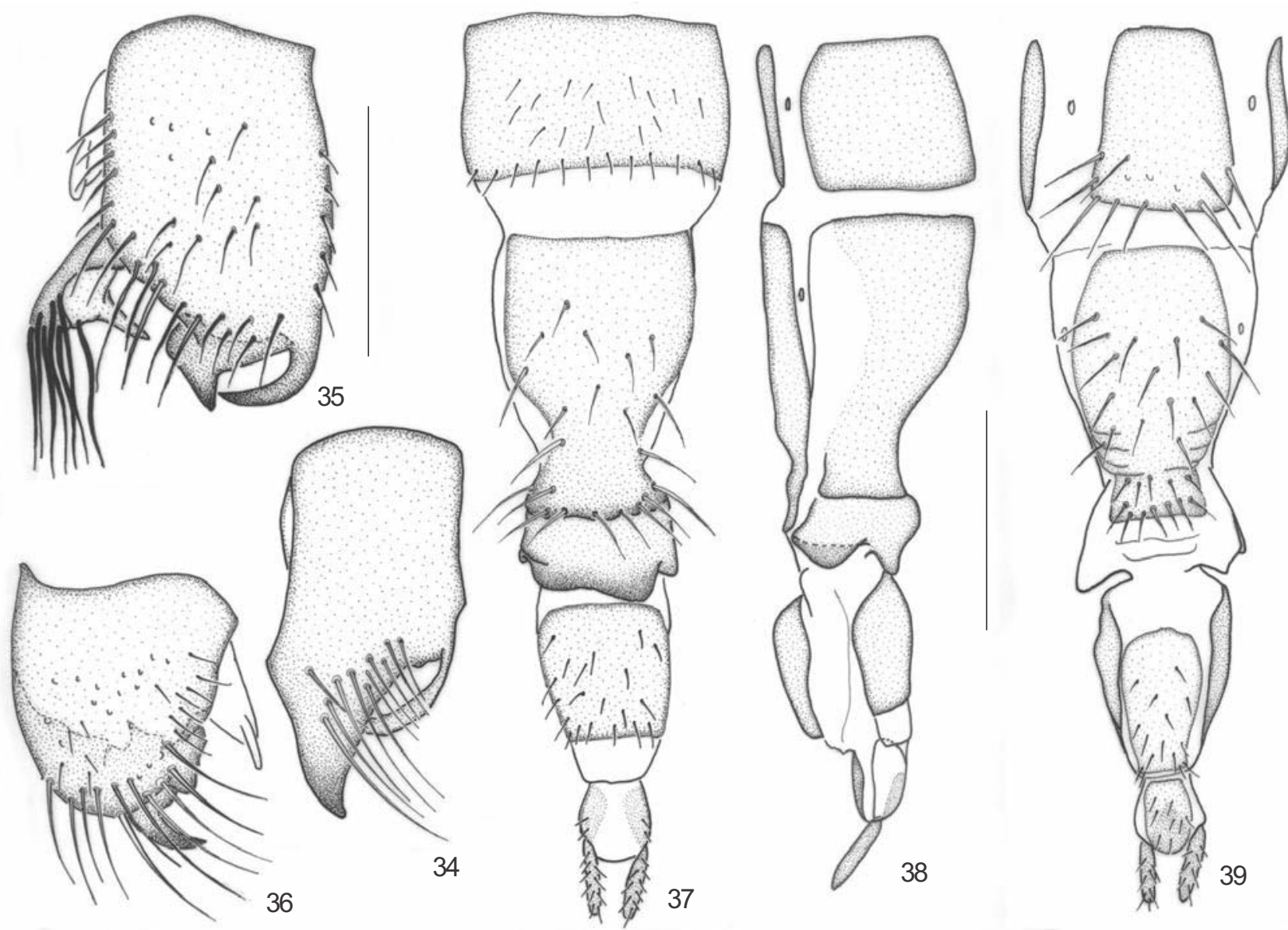

Figs. 34-39. Neohybos setosus sp. nov. Holotype male: 34, hypandrium, ventral view; 35, right epandrial lamella; 36, left epandrial lamella. Paratype female: 37-39, terminalia, dorsal, lateral and ventral view. Scale bars: Figs. $34-36=0.3 \mathrm{~mm} ; 37-39=0.5 \mathrm{~mm}$.

V row with 9 spines at distal half and $3 \mathrm{PV}$ distal setae; scutellum with 3 pair of spines; abdomen brown to black with gray pruinescence on $\mathrm{T} 1$, medial band on $\mathrm{T} 2$ and base of $\mathrm{T} 8$; dorsolateral setae of T4 absent. Terminalia (Figs. 37-39): T8 and S8 entire; cercus slender.

Holotype male, DOMINICAN REPUBLIC. La Veja: $9 \mathrm{Km} \mathrm{SE}$ Constanza near Valle Nueco. 18-50N, 70-42W, 1930m, 17.VIII.1990 J. E. Rawlins, S. Thompson (dissected, CMNH). Paratypes: Pedernales, $7 \mathrm{Km}$ NE Los Arroyos, 1870m (18-16N, 71-44W), 15.VII.1990, L.Masner, C.Young, J. Rawlins, intercept trap, 1 female (CMNH).

Remarks. Neohybos setosus sp. nov. is very close to $N$. pruinosus sp. nov. differing by the male with a straight hind tibia, hind femur with ventral spines arranged in straight line with bases slightly protuberant, male scutellum with 4 pairs of stout setae and all tarsomeres dark brown to black.

The specific name refers to long setae on right bacilliform sclerite.

Syneches Walker, 1852

Syneches Walker, 1852:165 (genus description); Melander, 1928:38 (key); 1965:448 (catalog); Smith, 1967:9 (catalog); 1977:190 (catalog); 1980:435 (catalog); 1989:389 (catalog); Wilder, 1974:1 (revision); Chvála \& Kovalev, 1988:184 (catalog).

Type species: Syneches simplex Walker, 1852:165 (mon.).

Six species have been previously recorded from the following islands of the West Indies: Jamaica, Puerto Rico, Dominica and Saint Vincent (Sмith 1967; Wilder 1974).

Key to species of Syneches recorded to West Indies

1. Hind femur swollen with AV row of spine-like setae; prosternum enlarged and partially articulated with the propleural sclerites

Hind femur slender with AV row of long slender setae; small isolated saddle-shaped prosternum .. 5

2(1). Pterostigma short, rectangular or oval (Figs. 53, 54); hind tibiae and tarsus simple 3

Pterostigma elongated, nearly filling the apex of cell $\mathrm{r}_{2+3}$; hind tibia distinctly clavate; hind first tarsomere swollen S. inversus Curran

3(2). Hind leg mainly dark brown except for trochanter and 

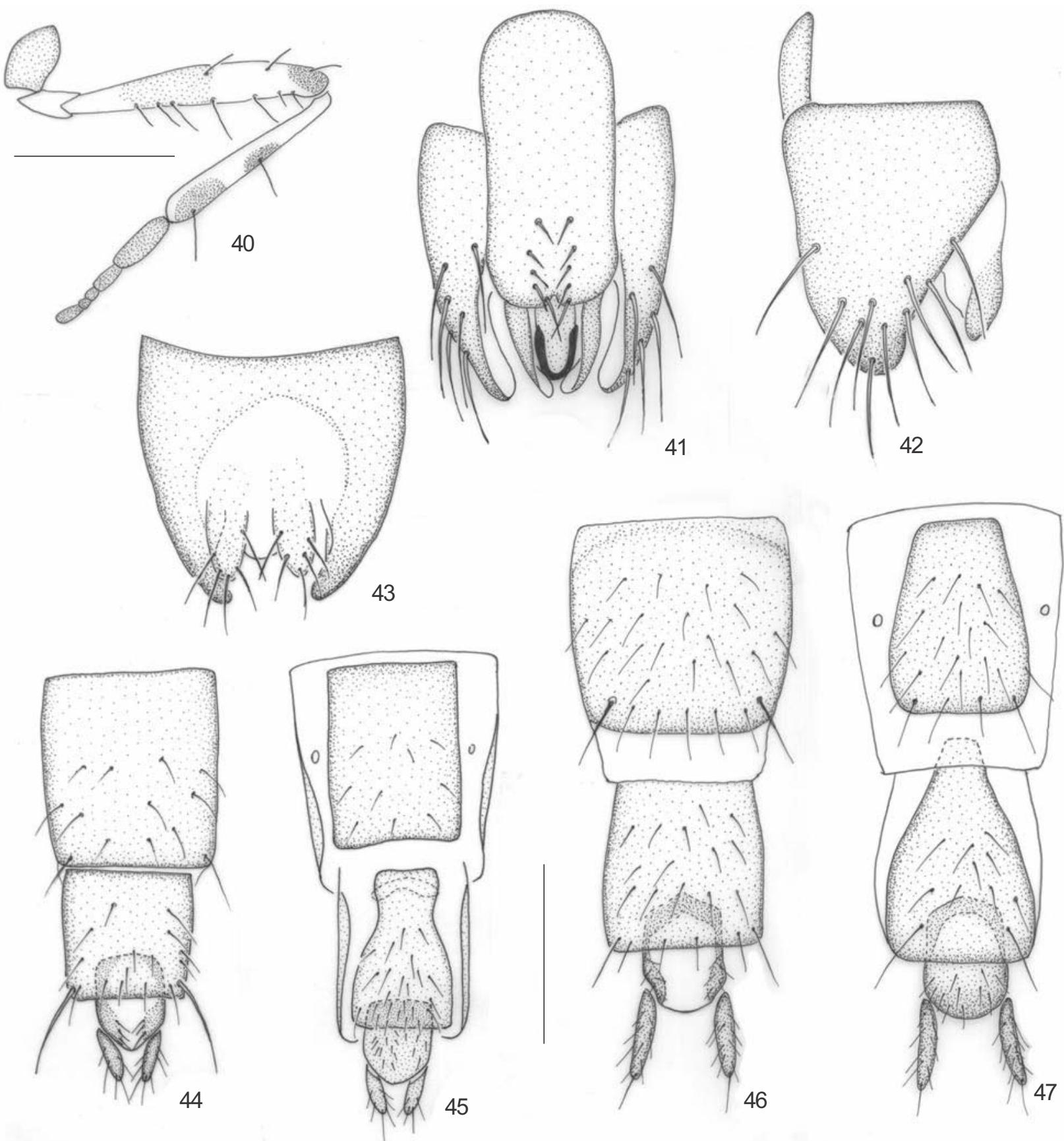

Figs. 40-47. Syneches dominicanus sp. nov. Holotype male: 40, hind leg, anterior view; 41, epandrium, hypandrium, postgonites and phallus, ventral view; 42, epandrium, hypandrium and cercus, lateral view; 43, epandrium and cercus, dorsal view. Paratype female: 44-45, terminalia, dorsal and ventral view. $S$. inversus: 46-7, female terminalia, dorsal and ventral view. Scale bars: fig. $40=1.0 \mathrm{~mm} ; 41-47=0.3 \mathrm{~mm}$.

bases of femur and tibia yellowish

S. macrochaetosus Wilder

Hind leg mainly yellow with a brown median band on femur and tibia

... 4

4(3). Hind coxa and tip of hind tibia yellow (WILDER 1974, fig. 13), apex of hypandrium with deeply bilobed projection (WILDER 1974, fig. 47) S. pallidus Wilder Hind coxa and tip of hind tibia brown (Fig. 40), hypandrium with narrow and short median apical notch (Fig. 41)...... S. dominicanus sp. nov.

5(1). Wing slightly brownish or yellowish; pterostigma slightly dark yellow tinged (WILDER 1974, fig. 56)

S. pusillus Loew Wing hyaline; pterostigma hyaline or gray (WILDER 1974, figs. 50, 54, 61) S. vineus Wilder. 

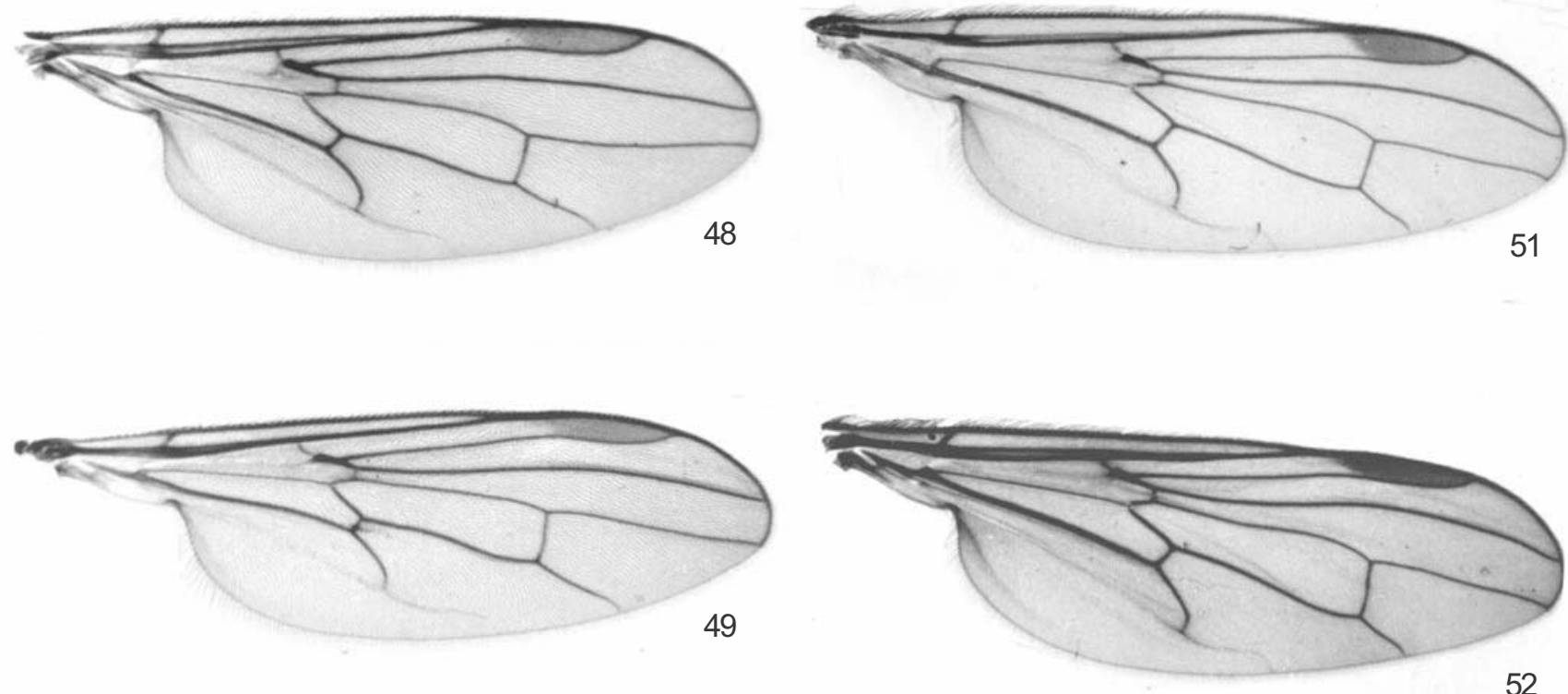

52
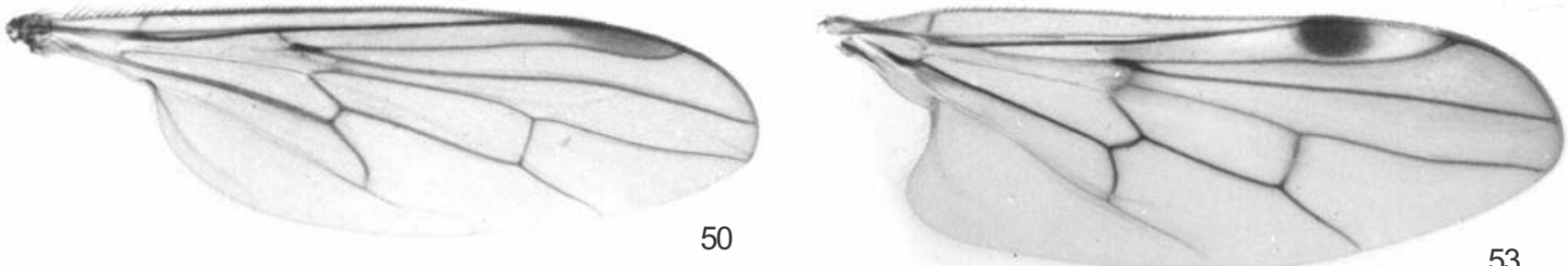

50

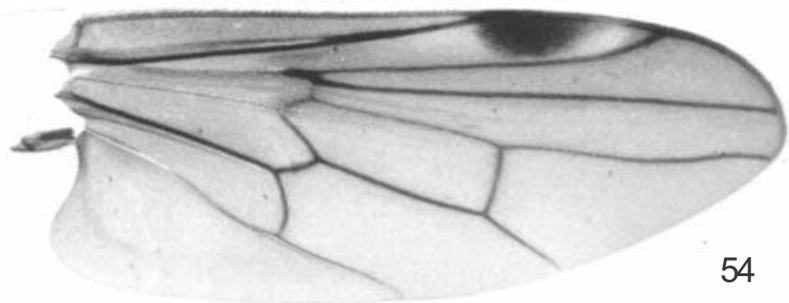

Figs. 48-54. Wings. 48, Euhybus martiniensis sp. nov.; 49, Neohybos cinereus sp. nov.; 50, $N$. longicornis sp. nov.; 51, $N$. pruinosus sp. nov.; 52, N. setosus sp. nov.; 53, Syneches dominicanus sp.nov. (holotype); 54, Syneches dominicanus sp. nov. (paratype).

\section{Syneches dominicanus sp. nov.}

(Figs. 40-45, 53, 54)

Diagnosis: thorax brown; anterior half of scutum brown pruinose dorsally, gray pruinose on posterior disc and laterally, with dorsocentral stripe and small notopleural brown pruinose spot; prosternum enlarged; fore and mid leg yellow except coxae, trochanters and distal tarsomeres brownish; hind leg yellow except coxa brown, femur with wide brown band at middle and dark brown tip, tibia with AD brown spot at middle and preapically, tarsus brown dorsally; pterostigma brown; abdomen brown, basal portion of $\mathrm{T} 2$ yellow.
Holotype male. Body length $5.2 \mathrm{~mm}$; wing length $4.7 \mathrm{~mm}$. Head. Antenna brown; arista yellow, inconspicuously short haired; first flagellomere blunt ended. Face broad, brown, gray pruinose. Proboscis yellow; palpus with 2 long setae, inner surface bare. Postcranium black, gray pruinose, with yellow slender setae; postocular uniserial, very short in upper half, elongated below; inferior half of postcranium with long and numerous occipitals. Ocellar tubercle protuberant; two ocellar divergent pair.

Thorax brown, pronotum and postpronotal lobe slightly paler than scutum; postalar callus and scutellum pale-brown to yellow. Anterior half of scutum brown pruinose dorsally, 
gray pruinose on posterior disc and laterally, with dorsocentral stripe and small brown pruinose notopleural spot; postpronotal lobe, pronotum and scutellum gray pruinose; pleurae gray pruinose except small shiny area on anepisternum and katepisternum. Pronotum with yellow setae on anterior margin and developed seta on posteroventral margin. Acrostichal setae with 3-4 anterior rows and 1 row on posterior disc; dc uniserial. Outstanding setae: $1 \mathrm{ntpl}$; $1 \mathrm{dc}$ posterior; 1 spal; 1 pal; 1 subapical sctl pair long and strong, 1 apical pair and 3 lateral long slender setae.

Legs: fore and mid leg yellow except coxae, trochanters and distal tarsomeres brownish; hind leg (Fig. 40) yellow except coxa brown, femur with wide brown band at middle and dark brown tip, tibia with AD brown spot at middle and preapical, tarsus brown dorsally. Outstanding setae: fore tibia with 4D; mid tibia spinose with $1 \mathrm{AD}$ and $1 \mathrm{PV}$ median long setae, 1P short at distal quarter, $1 \mathrm{~V}$ apical seta as long as that on tarsomere 1, 1AV submedian and $1 \mathrm{AV}$ preapical short setae; hind femur slightly swollen with $1 \mathrm{AD}$ submedian, $1 \mathrm{AD}$ near apex and 1D apical setae, AV row with 7 strong setae longer at middle of femur, $\mathrm{V}$ row with 5 short spines at apical half, 1PV long at distal quarter; hind tibia with $1 \mathrm{AD}$ at middle, $1 \mathrm{AD}$ preapical long seta and 1A apical short spine-like setae; hind tarsomere 1 with $1 \mathrm{~V}$ spine.

Wing (Fig. 53) yellow with costal margin slightly darker; pterostigma brown; veins yellow. Terminalia (Figs. 41-43): hypandrium with narrow and short median apical notch.

Abdomen brown except for basal portion of T2 yellow, with pale-brown pruinescence. Setae yellow, slender, short dorsally, long laterally but decreasing in length toward apex of abdomen.

Female. Similar to male except as follows: flagellum with 1D seta; pterostigma short with apex truncate. Terminalia as shown (Figs. 44, 45).

Holotype male. DOMINICAN REPUBLIC. La Vega: $9 \mathrm{Km} \mathrm{SE}$ Constanza near Valle Nuevo. 18-50N, 70-2W 1930m, 17.VIII.1990, J. E. Rawlins, S. Thompson (dissected, CMNH). Paratypes: same data as holotype, 1 female $(\mathrm{CMNH}), 1$ male (INPA).

Variations: the paratype differs from holotype by more slender hind femur, without a wide brown band at the middle and the pterostigma is semicircular (Fig. 54).

Remarks. Syneches dominicanus sp. nov. is very close to S. pallidus Wilder differing by the oval or semicircular pterostigma and hypandrium with narrow and short median apical notch. In $S$. pallidus, the psterostigma is rectangular and the hypandrium has a deeply bilobed projection apically.

\section{Syneches inversus Curran, 1928}

(Figs. 46, 47)

Syneches inversus Curran, 1928:35; Smith, 1967:10 (catalog); Wilder, 1974, figs. 3, 28, 48 (redescription).

This species has been previously recorded only from
Jamaica. It was redescribed by WILDER (1974) with drawings of the male terminalia, legs and wing. It differs from all other Syneches species by the following combination of characters: pterostigma elongated, almost filling the apex of cell $\mathrm{r}_{2+3}$; hind tibia distinctly clavate and hind first tarsomere swollen.

The female was unknown until now. Several female specimens from the Carnegie Museum were compared with the holotype male examined by us and considered conspecific. Terminalia (Figs. 46,47): ovipositor short, cercus small.

Holotype male. JAMAICA. Asichona, 2.VIII.1926 (n 1339, BMNH). Paratype: 25.VII.1923, 1 male ( ${ }^{\circ} 1194$, AMNH).

Additional material. DOMINICAN REPUBLIC. Pedernales: 3,3 Km NE Los Arroyos, 18-15N, 71-45W, 1450m, 16-18.VII.1990, L. Masner, J. Rawlins and C.Young, wet montane forest, sweep samples, 1 male, 1 female (CMNH), 2 males, 1 female (INPA); La Abeja, $38 \mathrm{Km}$ NNW Cabo Rojo, 18-09N, 71-38W, 1250m, 15.VII.1987, J. E. Rawlins, R. L. Davidson, 1 male, 1 female (CMNH), 1 female (INPA); Upper las Abejas, $38 \mathrm{Km}$ NNW Cabo Rojo, 18-09N, 71-38W, 1350m, 22.VII.1990, L. Masner, mesic deciduous forest, sweeping, 1 female (CMNH).

Distribution. Jamaica, Dominican Republic (new record).

Syneches pallidus Wilder, 1974

Syneches pallidus Wilder, 1974:15, figs. 13, 22, 47, 62.

This species was described from a Jamaican specimen. The Dominican Republic specimens represent the first record of the species after its original description. The holotype was examined and those specimens differ from him by their smaller length, darker color and more slender phallus.

Holotype male. JAMAICA, 4000' Hardwar Cap, 13.VII.1966, Howden \& Becker ( $\mathrm{n}^{\circ}$ 12692, CNC). Paratype: same data as holotype, 1 hallotype (CNC).

Additional material. DOMINICAN REPUBLIC. Hato Mayor: Parque Los Haitises, 3 Km W Cueva de Arena, 19-04N, 69-29W, 20m, 79.VII.1992, R. Davidson, J. Rawlins, S. Thompson, C. Young, mesic lowland forest, 2 males, 1 female $(\mathrm{CMNH}), 1$ male (INPA); Pedernales: 37 Km N Cabo Rojo, 4 Km E La Abeja, 18-10N, 71-37W, 1440m, 1316.VII.1987, R. L. Davidson, J. E. Rawlins, 1 male (CMNH).

Distribution. Jamaica, Dominican Republic (new record).

\section{Syneches vineus Wilder, 1974}

Syneches vineus Wilder, 1974:22, figs. 5, 29, 43, 50.

The original description including drawings of legs, wing and male terminalia is adequate. WILDER (1974) described this species including three subspecies: $S$. vineus vineus from Dominica, $S$. vineus jamaicensis from Jamaica and $S$. vineus medinai from Puerto Rico. The three subspecies differ by the pterostigma color and hypandrium. Unfortunately being preserved in alcohol for a long time damaged the wings of the examined material. The holotype was examined.

Holotype male. JAMAICA. 4000' Hardwar Cap. 25.VII.1966 Howden \& Becker (Syneches vineus jamaicensis, CNC). Paratype: 
same data asa holotype, hallotype (CNC).

Additional material. DOMINICAN REPUBLIC. Azua: east side of crest, Sierra Martin Garcia, 7 Km WNW Barrero, 18-21N, 70-58W, 860m, 25-25.vii.1992, C.Young, R.Davidson, S. Thompson, J. Rawlins, cloud forest adjacent to disturbed forest, 2 females (CMNH), 2 females (INPA); Bahoruco: Sierra de Neiba, Los Guineos on upper Rio Colorado, 18-35N- 71-11W, 630m 11-12.VIII.1990, J. Rawlins, S. Thompson, mesic riparian woodland, 1 female $(\mathrm{CMNH})$.

Distribution: Dominica, Puerto Rico, Jamaica, Dominican Republic (new record)

Acknowledgments. We thank Chen W. Young $(\mathrm{CMNH})$, D. Grimaldi $(\mathrm{AMNH}), \mathrm{J} . \mathrm{M}$. Cumming (CNC) and J. Chainey (BMNH) for the loan of the specimens.

\section{REFERENCES}

Ale-Rocha, R. 2002. Revisão do gênero Euhybus Coquillett (Diptera, Empididae, Hybotinae) da Região Neotropical. Grupo dimidiatus. Acta Amazonica 32: 299-324.

Ale-Rocha, R. \& C. J. B de Carvalho. 2003. Neohybos gen. nov. (Diptera, Empidoidea, Hybotinae) from the Neotropical Region. Zootaxa 387: $1-16$

Bezzi, M. 1909. Beitraege zur Kenntniss der südamerikanischen Dipterenfauna. Fam. Empididae. Nova Acta Leopolino-Carolinae 91: 297-406.

Chvála, M. \& V. G. Kovalev. 1988. Family Hybotidae, p. 174-227. In: A. Soós \& L. PApp (Eds.) Catalogue of Palaearctic Diptera. Volume 6. Budapest, Akademiai Kiadó, 435 p.

Coquillett, D. W. 1895. Revision of the North America Empidae - A family of two-winged flies. Proceedings of the United States National Museum 18: 387-440.

Coquillett, D. W. 1903. The genera of the dipterous family Empididae, with notes and new species. Proceedings of the Entomological Society of Washington 5(4): 245-272.

Cumming, J. M. 1992. Lactic acid as an agent for macerating Diptera specimens. Fly Times 8: 7 .

Cumming, J. M.; B. J. Sinclair \& D. M. Wood. 1995. Homology and phylogenetic implications of male genitalia in Diptera-Eremoneura.
Entomologica Scandinavica 26: 121-152.

Curran, C. H. 1928. Records and descriptions of Diptera, mostly from Jamaica, p. 29-45. In: C. C. Gowdey (Ed.). Catalogus Insectorus Jamaicensis. Kingston, Entomological Bulletin of Department of Agriculture of Jamaica.

Dalmau, P. A. \& I. G. Ávila. 1983. Lista anotada de los Dípteros de Cuba.Ciudad de La Habana, Editorial Científico-Técnica, 201 p.

McAlpine, J. F. 1981. Morphology and terminology-Adults, p. 9-63. In: J. F. McAlpine; B. V. Peterson; G. E. Shewell; H. J. Teskey; J. R. Vockeroth \& D. M. Wood (Eds). Manual of Nearctic Diptera. Volume 1. Ottawa, Research Branch, Agriculture Canada.

Melander, L. 1928. Diptera, Fam. Empididae, p. 1-434. In: P. Wystman (Ed.). Genera Insectorum. Volume 185 (1927). Bruxelles.

Melander, L. 1965. Family Empididae (Empidae, Hybotidae), p. 446481. In: A. C. Stone; W. Sabrosky; W. W. Wirth; R. H. Foote \& J. R. Coulson (Eds.). A Catalog of the Diptera of America North of Mexico. Washington, Agriculture Research Service, United States Department of Agriculture.

Rafael, J. A \& R. Ale-Rocha. 1995. Revisão das espécies neotropicais de Empididae (Diptera) descritas por Mario Bezzi. I. Hybotinae. Revista Brasileira de Entomologia 39(3): 517-546.

Rogers, E. 1983. The Neotropical species of Drapetis Meigen (Diptera:Empididae). Systematic Entomology 8: 432-452.

Sмiтн, K. G. V. 1967. Family Empididae, p.1-67. In: A Catalogue of the Diptera of Americas South of the United States. Volume 39, São Paulo, Departamento de Zoologia, Secretaria da Agricultura.

Sмiтн, K. G. V. 1977. Family Empididae (Empidae, Hybotidae), p.185211. In: M. D. Delfinado \& D. E. Hardy (Eds.). A catalog of the Diptera of the Oriental region. Vol. II. Suborder Brachycera through Division Aschiza, suborder Cyclorrapha. Honolulu, Univ. Press of Hawaii, 459 p.

Smith, K. G. V. 1980. Family Empididae, p. 431-442. In: R. W. Crosskey (Ed.). Catalogue of the Diptera of the Afrotropical Region. London, British Museum (Nat. Hist.), 1435 p.

Smith, K. G. V. 1989. Family Empididae, p. 382-392. In. N. L. Evenhuis (Ed.). Catalog of the Diptera of the Australasian and Oceanian Regions. Bishop Museum Press - Brill, 1155 p.

WALKer, F. 1849. List of the specimens of dipterous insects in the collection of the British Museum. Volume 3. London, $687 \mathrm{p}$.

Walker, F. 1852. Diptera. In: W. W. Saunders (Ed.): Insecta Saundersiana: or characters of undescribed insects in the collection of W.W. Saunders. London, 474 p. (transcrição).

WildeR, D. D. 1974. A revision of the genus Syneches Walker (Diptera: Empididae) for North America and the Antilles. Contribution of the American Entomological Institute 10: 1-30.

Received 07.V.2004; accepted 10.IX.2004 